\title{
1944 IRKÇILIK-TURANCILIK DAVASI VE BASINDAKİ TARTIŞMALAR
}

\author{
Hülya Öztekin*
}

\section{ÖZET}

İkinci Dünya Savaşı döneminde Türkiye'nin yürüttüğ̈̈ dış politika ve dönemin uluslararası politik koşulları, pek çok noktada iç politikaya ilişkin kararların ve uygulamaların da temel belirleyicisi olmuştur. Bu çerçevede siyasal iktidarın, özellikle savaş döneminde aktif hale gelen ve basın da dahil pek çok alanda etkinlik gösteren Turancı harekete karşı tutumu da ülkenin dış politikadaki manevralarına ve uluslararası konjonktüre bağhl olarak gelişmiştir. Almanya'yla kurulan dostane ilişkiler ve Almanya'nın savaşta aldı̆̆g galibiyetler bağlamında Turancı hareketin 1943 yılının sonlarma kadar resmî ideoloji tarafindan hoşgörüyle karşılanması, hatta bizzat hükümet çevrelerinde destek bulması; buna karşın Almanya'yla ilişkilerin kesildiği 1944 yılında Turancı hareketin de beklenmedik bir şekilde tasfiye edilmesi bu etkiyi açıkça ortaya koymaktadır. Turancı çevrelere yönelik bu tasfiye süreci Alman yanlısı ve Turanci yayınların teker teker kapatılmasılyla başlamış, Sabahattin Ali-Nihal Atsız davası sonrasında gelişen gözaltı ve tutuklamalar ve son olarak 'irkçılık-Turancılık davası' yla devam etmiştir. Bu çalışmada, Mayıs 1944'te başlayıp Mart 1947'de sona eren ve Türk siyasi literatürüne 'ırkçılık-Turancilık davası' olarak geçen davanın dönemin yazılı basınında ele alınış biçimi incelenmiştir. Çalışmanın amacl, Türk siyasi tarihinin önemli gelişmelerinden biri olan ırkçılık-Turancılık davası ve bu dava etrafında gelişen olayların dönemin iç ve dış siyasetiyle olan bağını ortaya koymak; ulusal gazetelerin bu davaya yaklaşımı çerçevesinde dönemin basın-iktidar ilişkilerine ışık tutmaktır. Tarihsel betimleyici analiz yöntemi ile hazırlanan çalışmada ilgili dönemde yayımlanan ulusal gazetelerden Akşam, Cumhuriyet, Tan, Tanin, Ulus, Vakit gazeteleri taranmuş, konu ile ilgili haber ve köşe yazıları analiz edilmiştir.

Anahtar Kelimeler: Irkçılık-Turancılık Davası, Turancılık, İkinci Dünya Savaşı, Tek Parti Dönemi Basını

\section{RACISM-TURANISM CASE AND DISCUSSIONS IN PRESS}

\section{ABSTRACT}

During the World War II, Turkey's foreign policy and international political conditions of term were also the main determinants of internal politics decisions and practices. In this context, the stance of political power against Turanist movement, which became active especially in the war term and played an active role in many fields including the press was formed in accordance with the maneuvers of Turkey in foreign political field and the international conjuncture. In the context of friendly relations with Germany and Germany's success in the war, the Turanist movement was tolerated by the official ideology until the end of 1943 and even supported by the government circles; whereas in 1944, when relations with Germany were cut off, the Turanist movement was also

\footnotetext{
*Yrd. Doç. Dr. Erciyes Üniversitesi İletişim Fakültesi
} 
unexpectedly liquidated. This liquidation process for Turanist circles started with the closing of the pro-German and Turanist publications one by one, continued with the detentions and arrests following the Sabahattin Ali-Nihal Atsiz case and finally with the 'Racism-Turanism case'. In this study, the form of handling in press of the case which started in May 1944 and ended in March 1947 and known as 'Racism-Turanism case' in Turkish political literature was examined. The aim of the study is to reveal the connection between the Racism-Turanism case which is one of the important developments of Turkish political history and the events that developed around this case with the internal and external politics of term; is to shed light on the press-power relations of term within the frame of main-stream newspapers' approach to this case. In the study which was prepared by the historical descriptive analysis method, the newspapers of Akşam, Cumhuriyet, Tan, Tanin, Ulus and Vakit were scanned and news and columns about the subject were analyzed.

Keywords: Racism-Turanism Case, Turanism, World War II, One-Party Period Press

\section{Gíriş}

Birinci ve İkinci Dünya Savaşı arasındaki dönemde dış politikadaki ana eğilimi Lozan Barış Antlaşması ile kurulan düzenin devam ettirilmesi yönünde olan Türkiye, İkinci Dünya Savaşı'nda da dış politikasını savaş dışı kalmak ve toprak bütünlüğünü korumak üzerine kurmuştur. Dolayısıyla Türk Hükümeti, kendi toprak bütünlüğüne herhangi bir saldırı gerçekleşmedikçe savaşa girmeme kararı almış ve bu yönde bir denge politikası geliştirmiştir. Bu politika çerçevesinde 19 Ekim 1939 tarihinde İngiltere ve Fransa ile üçlü ittifak anlaşması, 24 Mart 1941'de Sovyetler Birliği ile saldırmazlık anlaşması ve 18 Haziran 1941' de de Almanya ile bir dostluk ve saldırmazlık anlaşması imzalayan Türkiye bu sayede savaşan tarafların tamamıyla dostane ilişkiler kurmuş ve savaş dışı kalma planını garanti altına almaya çalışmıştır.

Bununla birlikte söz konusu tarafların savaştaki konumu ve askeri gücü, Türk dış politikasında kısmi değişikliklere yol açmıştır. Özellikle Almanya'nın 2 Mart 1941'de Balkanlar'a girerek Türk sınırına dayanması ve birbiri ardına aldığı zaferlerle savaşta üstün konuma gelmesi üzerine Türk dış politikasında değişiklikler olmuştur. Olası bir Alman saldırısını önlemek üzere 18 Haziran'da Almanya ile imzalanan dostluk anlaşmasından sonra hem siyasi çevrelerde hem de yazılı basın dahil olmak üzere Türk kamuoyunda belirgin bir şekilde Alman hayranlığ görünür hale gelmiştir. Aslında genel olarak bakıldığında Türkiye'nin savaş boyu izlediği dış politika ve dönemin uluslararası politik koşulları, pek çok noktada iç politikaya ilişkin kararların ve uygulamaların da temel belirleyicisi olmuştur.

1941 yılı haziran ayında Almanya'nın Sovyetler Birliği'ne saldırmasından sonra Türk basınında, Pan-Türkist ve Turancı (1) nitelikte yayınlar yapılmaya başlan- 
mış, özellikle Almanya'nın savaşta üstün olduğu 1941-1943 yıllarında sayılarında büyük bir artış görülmüştür (2). Basın üzerinde her türlü denetleme ve yönlendirme olanağına sahip olan tek parti iktidarı, bu yayınlara uzun süre ses çıarmamış, hoşgörülü davranmıştır. Bir başka deyişle Türkiye'nin Nazi Almanya'sı ile topraklarına bu ülke tarafından yapılabilecek bir saldırıyı önlemek amacından hareketle zoraki yakın ilişkiye girmesi sonucunda oluşan dış politika tavrı, iç politikaya yansımış ve iktidar, Pan-Türkist akıma ve yayınlara bir süre hoşgörülü davranmıştır (Güvenir 1991: 135). Bu tür yayınların artmasında, Alman propagandasının da büyük rolü olmuştur. Türkiye'nin Almanya yanında savaşa girmesini ya da en azından savaş dışı kalarak Müttefik safına geçmesini engellemek amacıyla Almanya, İkinci Dünya Savaşı boyunca Türkiye üzerinde yoğun propaganda faaliyetleri yürütmüştür. Bu propaganda faaliyetlerinin ana temalarından biri de Almanya Sovyetler Birliği'ni yendikten sonra Türklerin çoğunlukta yaşadığı Sovyet topraklarının Türkiye yönetimine bırakılabileceği ve bazı Türkçü çevrelerin yıllardır kurduğu 'Büyük Turan' hayalinin gerçekleşebileceği yönündeydi. Türkiye'nin Sovyetler Birliği’ne karşı Almanya yanında yer almasını amaçlayan bu propaganda Türk siyasi çevrelerinde de olumlu karşılanmış ve destek bulmuştur. Hatta Alman haber alma servislerinin edindiği bilgiye göre 1942 ilkbaharında parti ve hükümet yöneticileri arasında, başını Şükrü Saraçoğlu'nun çektiği bir Turancılık hücresi ya da lobisi bile kurulmuştur (Berkes 2005: 236).

Almanya'nın Ankara Büyükelçisi Von Papen'in etkin olarak yönettiği propaganda faaliyetlerinde pek çok farklı yöntem ve teknik kullanılmıştır. En etkin biçimde kullanılan yöntem kuşkusuz basını etkileyip kontrol altına almaktır. Bunun içinse para yardımı, araç-gereç yardımı (özellikle matbaa malzemesi ve telsiz), haber yardımı, gazete yöneticilerine Almanya seyahati temin etmek gibi yollara başvurulmuştur (Gözaydın 2002: 20). Almanlar, Türk basınını etkilemek üzere gazete sahiplerine, yazı işleri görevlilerine ve bazı gazetecilere çeşitli biçimlerde rüşvet vermişlerdir. Örneğin, Mart 1941'de Balkanlar'a yapılacak Alman baskını için Türkiye'nin tarafsızlığını güvenceye almak söz konusu olduğu zaman, Alman Dışişleri Bakanı Ribbentrop, 9 Mart'ta Almanya'nın Türkiye büyükelçisi Von Papen'e yolladığı bir telgrafta basının ve radyoda çalışanların parayla kandırılması için birkaç milyonun döviz olarak dağıtılmasını önermiştir. Von Papen ise buna verdiği karşılıkta, istenilen işin başarıyla yerine getirildiğini bildirmiştir (Glasneck 1976: 24).

Ne var ki 1943 yılı sonlarından itibaren Almanya'nın farklı cephelerde birbiri ardına aldığı yenilgilerden ve Almanya'yla ilişkileri kesme konusunda Müttefik ülkelerin Türkiye üzerindeki baskılarından sonra, Türk Hükümeti'nin Almanya politikasında ciddi bir dönüşüm yaşanmıştır. 1944 yılının nisan ayında Türkiye'nin Almanya'ya krom sevkiyatını durdurma kararı alması ve ağustosta da Almanya ile bütün siyasi ve ticari ilişkilerin kesilmesine paralel olarak hüküme- 
tin Alman yanlısı ve Turancı yayınlara gösterdiği hoşgörü sona ermiş ve Turancı çevrelere yönelik bir tasfiye hareketi başlatılmıştır. Önce Alman yanlısı ve Turanc1 yayınların teker teker kapatılmasıyla başlayan süreç, Sabahattin Ali-Nihal Atsız davası sonrasında gelişen olaylar ve literatüre 'ırkçılık-Turancılık davası' olarak geçen siyasi davayla devam etmiştir.

Bu çalışmada, Mayıs 1944'te başlayıp Mart 1947'de sona eren ve ülkenin dış politikadaki manevralarına göre seyreden 'irkçılık-Turancılık davası'nın dönemin yazılı basınında ele alınış biçimi incelenmiştir. Çalışmanın amacı, Türk siyasi tarihinin önemli gelişmelerinden biri olan ırkçılık-Turancılık davası ve bu dava etrafında gelişen olayların dönemin iç ve dış siyasetiyle olan bağını ortaya koymak; ulusal gazetelerin bu davaya yaklaşımı çerçevesinde dönemin basın-iktidar ilişkilerine 1şık tutmaktır. Tarihsel betimleyici analiz yöntemi ile hazırlanan çalişmada ilgili dönemde yayımlanan ulusal gazetelerden Akşam, Cumhuriyet, Tan, Tanin, Ulus, Vakit gazeteleri taranmış, konu ile ilgili haber ve köşe yazıları analiz edilmiştir.

\section{SABAHATTIN ALI-NIHAL ATSIZ DAVASI}

1944 yılının nisan ve mayıs aylarında gerçekleşen ve kamuoyunda 'Sabahattin Ali-Nihal Atsız davası' olarak bilinen dava, aslında 'ırkçılık-Turancılık davası'nın ilk perdesi olarak kabul edilebilir. Söz konusu süreç Nihal Atsız'ın, sahibi ve müdürü olduğu Orhun dergisinin 1 Mart 1944 tarihli 15. sayısında yayımlanan "Başvekil Saraçoğlu Şükrü'ye Açık Mektup" başlıklı yazıyla başlamıştır. "Hem Türkçü hem de başvekil olduğunuz için size bu açık mektubu yazıyorum" cümlesiyle yazısına başlayan Atsız, Şükrü Saraçoğlu'nun 5 Ağustos 1942 günü Meclis'te yaptığ1 konuşmasındaki “Biz Türküz, Türkçüyüz ve daima Türkçü kalacağız. Bizim için Türkçülük bir kan meselesi olduğu kadar ve lâakal o kadar bir vicdan ve kültür meselesidir." (3) sözlerini hatırlatarak bu sözlerin Türkçü çevrelerde büyük bir sevinçle karşılandığını, fakat bu konuşmanın üzerinden bir buçuk yıl geçmiş olmasına rağmen Türkçülüğün sözde kaldığını ve uygulamaya geçirilmediğini ifade etmiş; bir anlamda Saraçoğlu'ndan hesap sormuştur. Türkçülük sözde kalırken millet ve ülke düşmanı olan solcu fikirlerin bazen sinsice bazense açıtan propaganda yapmaya ve gençler arasında yayılmaya devam ettiğinden şikâyet etmiştir. Solculuğun müsamaha gördüğünü, devletin ve $\mathrm{CHP}^{\prime}$ nin solculara karşı kayıtsız kaldığını ifade eden Atsız, lise ve üniversitelerde devletin parasıyla okuyan solcu ve komünist gençlerin çoğaldığından, bu gençlerin Türkiye'nin geleceği açısından tehlike arz ettiğinden bahsetmiştir (Atsız 1 Mart 1944: 1-4).

Nihal Atsız, derginin 1 Nisan 1944 tarihli 16. sayısında "Başvekil Saraçoğlu Şükrü'ye İkinci Açık Mektup" başlıklı bir başka yazı daha yayımlamıştır. Bu yazısında da ülkedeki sinsi komünistlerin varlığından şikâyet eden Atsız "maarif sahasına girmiş olan komünistlerden" bahsederek bunların vatan düşmanlarına karşı 
kayıtsız davranan Maarif Vekillerinin gafletinden faydalanarak mühim yerlere geldiklerini ve oradan zehirlerini saçmaya başladıklarını iddia etmiştir. 'Maarif sahasındaki komünistler'e örnek olarak Sabahattin Ali, Pertev Naili Boratav, Sadrettin Celal Antel ve Ahmet Cevat isimlerini veren yazar, bu kişilerin Maarif Vekili Hasan Ali Yücel'in sempatisi sayesinde önemli görevlerde bulunduklarını dile getirmiş, bu durumun vatansever Türkçü gençlerin vicdanını rahatsız ettiğini yazmıştır. Mektubun sonunda ise Hasan Ali Yücel'in bu isimlerin görevlerine son vermesi gerektiğini, hatta kendisinin de Maarif Vekilliği'nden ayrılmasının vatansever bir davranış olacağını söylemiştir (Atsız 1 Nisan 1944: 1-6).

Bu mektuplar üzerine Maarif Vekaleti Nihal Atsız'ın Özel Boğaziçi Lisesi'ndeki öğretmenlik görevine son vermiştir. Ayrıca hükümet kararıyla çıkardığı Orhun dergisi de kapatılmıştır (Müftüoğlu 1974: 42).

Nihal Atsız'ın ikinci yazısında adı geçen Sabahattin Ali, kendisine 'vatan haini' dediği gerekçesiyle Atsız aleyhine hakaret davası açmıştır. Darendelioğlu (1968: 116) ve Müftüoğlu'na (1974: 43) göre, Sabahattin Ali söz konusu davayı Maarif Vekili Hasan Ali Yücel ve Ulus gazetesi başyazarı Falih Rıfkı Atay'ın teşvikiyle açmıştır. Ayrıca Ulus gazetesi hukuk müşaviri de Sabahattin Ali'nin avukatlığını üstlenmiştir.

Sabahattin Ali-Nihal Atsız davasının 26 Nisan 1944'te gerçekleşen ilk duruşmasinda mahkeme salonu Nihal Atsız'ı desteklemeye gelen büyük bir kalabalık tarafından doldurulmuş, mahkeme heyeti salona camdan girmek zorunda kalmıştır. Kalabalık ve izdiham nedeniyle duruşma yapılamamış ve öğleden sonraya ertelenmiştir (Darendelioğlu 1968: 116).

Sabahattin Ali ve Nihal Atsız arasındaki bu dava daha ilk duruşmadan itibaren taraflar arasındaki kişisel bir hakaret davası olmaktan çıkmış, '1rkçılıkkomünistlik' davasına dönüşmüştür. Türk kamuoyunda Nihal Atsız ve Sabahattin Ali dönemin sağcı ve solcu akımlarının temsilcileri olarak görünüyorlardı. Atsız ırkçı milliyetçi olarak biliniyor, Sabahattin Ali'nin ise Bolşevik sempatizanı olduğu düşünülüyordu. Atsız'ın mektupları aslında birbirlerine siyasal husumetlerini geçmişten beri dile getiren iki karşıt grup arasındaki anlaşmazlığı yeniden alevlendirmiştir (Özdoğan 2002: 97-98). Nihal Atsız'ın avukatı Hamit Şevket İnce'nin, 26 Nisan'da görülen ilk duruşmada bunun basit bir hakaret davası olmadığı, iki inancın yani milliyetçilik ve komünizmin çarpışması davası olduğu yönündeki açıklaması da bunun açık bir ifadesidir (4).

Davanın ilk duruşmasının yapıldığı gün gazetelere Basın Yayın Genel Müdürlüğü aracılığıyla şu talimat gönderilmiştir: "Nihal Atsız ve Sabahattin Ali davası hakkında kommanter yapılmamasını, makale yazılmamasını, mahkeme safhalarına ait haberlere son verilmesini rica eder, müteakip mahkemelere ait ayrıca 
iş'aratta bulunulacağını arz ederim." -Basın Yayın Umum Müdürü (Kabacalı 1987: 20-21).

Davanın ilk duruşması Vakit gazetesi tarafından "Sabahaddin Ali-Nihal Atsız Davasına Dün Ankara'da Başlandı" başlığıyla duyurulmuştur (27 Nisan 1944). Duruşmanın seyrinden bahsedilen haberde davaya ilişkin herhangi bir yorum yapılmamıştır. Benzer şekilde Tan gazetesinde "Adsız Aleyhindeki Davaya Başlandı" (27 Nisan 1944), Tanin gazetesinde "Orhun Mecmuası" (27 Nisan 1944), Cumhuriyet gazetesinde "Açık Mektub'dan Çıkan Dava", Akşam gazetesinde de "Sabahaddin Ali-Nihal Adsız Davasına Başlandı" (27 Nisan 1944) başlıklarıyla davanın başladığı haber verilmiştir.

Ulus gazetesi ise söz konusu duruşmaya hiç yer vermezken iki gün sonra dolaylı olarak konuya değinmiştir. Falih Rıfkı Atay 29 Nisan tarihli başyazısında Sabahattin Ali-Nihal Atsız davasıyla gündeme gelen ırkçlık-komünizm karşıtlığına gönderme yaparak Türkiye'de bu iki ideolojiye de yer olmadığını şu sözlerle ifade etmiştir:

Bu vatanın içinde bir tek millet vardır. Onun adına Türk milleti derler. Bu rejimi yoğuran tek bir kanun var. Onun adına Anayasa derler. Bu memlekette ne Alman ırkçılı̆̆ın doğuran tarihi, siyasi ve içtimai buhranlar, ne de demokrasileri să̆ ve sol cereyanlar içinde parçalayan sınıf tezatlaşmalar var. Anayasa prensipleri bizde birleştirici, yoğurucu ve artırıcı bir disiplin kurmuştur. Ayırıcl, dağıtıcı ve azaltıcı bütün ideolojiler, taklittirler, özentidirler, yapmaciktırlar: bu vatanla bu millete yabancıdırlar (Falih Rifkı Atay, "Yaşadığımız Zaman”, Ulus, 29 Nisan 1944).

30 Nisan tarihli Tanin'de Falih Rıfkı Atay'ın 29 Nisan'da Ulus'ta yayımlanan başyazısına yer verilmiştir. "Sağ-Sol Cereyanları" başlıklı haberde "Falih Rıfkı Atay bugünkü makalesini memleketimizdeki sağ-sol cereyanlara hasrederek bu memlekette ne Alman ırkçılı̆̆ın doğuran tarihi, siyasi ve içtimai buhranlar; ne de demokrasileri sağ-sol cereyanlar için parçalayan sınıf tezatlaşmaları var demekte ve bu yüzden hiçbir tehlike karşısında olmadığımız, böyle bir tehlike belirdiği vakit Millet Meclisinin anayasayı nasıl müdafaa edeceğini ve ona herkesi nasıl itaat ettireceğini bildiğini ifade ederek şöyle demektedir" ifadeleriyle Atay'ın yazısından bahsedilmiş ve devamında yazıdan aynen alıntılar yapılmıştır (Tanin, "Sağ-Sol Cereyanları", 30 Nisan 1944).

Basın Yayın Genel Müdürlüğ̈̈'nün yukarıda bahsi geçen ve davaya ilişkin haber, makale ve yorum yapılmasını yasaklayan talimatnamesi nedeniyle Tanin bizzat kendisi konuyla ilgili yazı yayımlamak yerine Falih Rıfkı Atay'ın yazısına yer vermeyi tercih etmiştir. Aslında sadece Tanin değil dönemin diğer ulusal gazeteleri de benzer şekilde Atay'ın yazılarını aynen ya da kısmen yayımlama yolunu gitmişlerdir. Çünkü o dönemde CHP'nin yayın organı olan Ulus gazetesinin baş- 
yazarlığını yapan Falih Rıfkı Atay, aynı zamanda CHP milletvekilidir. Dolayısıyla Atay'ın yazıları, hükümetin görüşünü yansıttığı için onun yazılarını aktarmak mevcut yasağa aykırı davranmak anlamına gelmiyordu.

Davanın bir sonraki duruşması 3 Mayıs 1944 günü yapılmıştır. Bu ikinci duruşmaya gelen ve Atsız'1 destekleyen kalabalık, mahkeme salonunda Atsız'ı alkışlamaya ve "Kahrolsun Komünistler" diye bağırmaya başlamıştır. Aynı kalabalık dışarıda da alkış ve tezahüratlara devam etmiş, adliyeden Ulus meydanına doğru yürüyüşse geçmiştir. Ulus meydanında komünizm aleyhine konuşmalar yap1lıp İstiklal Marşı söylendikten sonra Başvekâlet'e giderek Başvekil Şükrü Saraçoğlu lehine tezahüratlar yapılmıştır. Ardından göstericiler tekrar adliye binasına doğru yürümüşlerdir. Bu esnada Sabahattin Ali'nin kitaplarını da yakmışlardır. Olaylara müdahale eden polislerle göstericiler arasında çatışma yaşanmış, polis göstericilerden bazılarını gözaltına almıştır. Hatta göstericiler olay yerinde İstiklal Marşı okuyarak polisi durdurma yoluna gitmişler, bazıları bu sayede polisin elinden kaçabilmiştir (5) (Darendelioğlu 1968: 117-118; Goloğlu 1974: 248; Sülker 1968: 22).

3 Mayıs günü yapılan gösteriler ve beraberinde yaşananlar ulusal gazetelerde yer almamıştır. Tanin, Vakit, Cumhuriyet ve Akşam gazeteleri 3 Mayıs tarihli duruşmaya ilişkin haber yayımlamış; fakat hiçbiri yaşananlardan bahsetmemiştir ( $\mathrm{Ta}$ nin, "Nihal Atsız ve S. Ali Davası", 4 Mayıs 1944; Vakit, "Sabahattin Ali Davası", 5 Mayıs 1944; Cumhuriyet, "Sabahaddin Ali-Nihal Adsız Davası", 4 Mayıs 1944; Akşam, "Sabahaddin Ali-Nihal Adsız Davası", 4 Mayıs 1944).

Ulus gazetesi Sabahattin Ali-Nihal Atsız davası ve 3 Mayıs olaylarından ilk kez 7 Mayıs'ta açıkça bahsetmiştir. Başyazar Falih Rıfkı Atay “Nizam Düşmanlığ1 Yaptırmayız" başlıklı yazısında "Vakayı herkes biliyor: Istanbul'da bulunan bir öğretmen, Ankara'da bulunan bir öğretmene 'vatan haini' diye hakaret etmiştir. Hakarete uğrıyan vatandaş mahkemeye giderek adalet istemiştir. Zabıta tahkikatı ile meydana çıktığına göre, birkaç tahrikçi, bir avuç genci aldatarak, mahkemenin içinde ve dışında, tertipli nümayişlerde bulunmuşlar, akıllarında davacıyı tedhiş etmek, hakimi ve Hükümeti tesir altına almak yeltenişinde bulunmuşlardır. Suçlular sorguya çekilmiş, aldatılmış olanlar serbest bırakılmıştır. Olup biten bundan ibaret!" sözleriyle 3 Mayıs olaylarını, birkaç tahrikçinin bir avuç genci (6) 'aldatarak' tertiplediği basit bir olay şeklinde aktarmaktadır. Bu tahrikçileri, Romanya'nın başına milli tarihinin en büyük felaketini getiren Gardistlerin basit taklitçileri (7) olarak niteleyen Atay, gösterilere katılanların kandırılmış gençler olduğunu ısrarla vurgulamıştır. “Cumhuriyet, Türkiye'de hür kafalar ve hür vicdanlar rejimi kurmuştur: bu rejim, ithal malı cebir anarşi cereyanlarnna karşı korunmakla devam edebilir. Hemen söyleyelim ki memleket, birkaç tahrikçinin şamatası yüzünden herhangi bir anarşi tehdidine ne uğramıştır ne de uğrar." diyerek bu tür eylemlerin başarıya ulaşamayacağını ifade etmiştir (Falih Rıfkı Atay, "Nizam Düşmanlığı Yaptırmayız”, Ulus, 7 Mayıs 1944). 
Falih Rıfkı Atay'ın bu yazısı aynı gün diğer gazetelerde de yayımlanmıştır. Tan, Atay'ın yazısını "Ulus'un Makalesi” (7 Mayıs 1944) başlığıyla aktarırken, Vakit "Ulus'un mühim bir makalesi" (7 Mayıs 1944), Cumhuriyet "Nizam Düşmanları" (7 Mayıs 1944) başlığı altında yayımlamıştır. Tanin ve Akşam ise Ulus'un başlığını aynen kullanarak “Nizam Düşmanlığı Yaptırmayız" başlığı altında Atay'ın yazısına yer vermiştir (7 Mayıs 1944). Görüldüğü üzere 3 Mayıs'ta hiçbir şey olmamış gibi davranan ulusal basin, konu ancak Ulus gazetesinde yer bulduktan sonra yine $U l u s^{\prime}$ un ifadeleriyle konuyu haber yapabilmiştir.

Dava sürecinde ilginç bir gelişme yaşanmıştır. Nihal Atsız'ın avukatı Hamit Şevket İnce, 7 Mayıs 1944 tarihinde davadan ve Atsız'ın avukatlığından çekildiğini açıklamıştır. Ulus gazetesine yazdığı mektupta bu kararının gerekçesini anlatan İnce, bazı dostlarının kendisini uyarması üzerine müvekkili Atsız'ın geçmişte yazdığ 1 'Dalkavuklar Gecesi' isimli kısa romanı okuduğunu ve burada Atatürk'le alay edildiğini, aşağılandığını gördüğünü ifade etmiştir. Ayrıca Atsız’n bir Türk milliyetçisi olmadığını da anladığını, kendisinin bilmeden ırkçı ve Turancı bir amaca alet edilmek istendiğini, vicdanının sesini dinleyerek Nihal Atsız'1 müdafaa etmemeye karar verdiğini açıklamıştır (Ulus, "Hamit Şevket İnce Nihal Adsız’ın Avukatlı̆̆ından İstifa Etti", 8 Mayıs 1944).

Oysa davanın başladığı ilk günlerde gazetecilere açıklama yapan Hamit Şevket İnce, "Ben eski Ocaklı bir Türküm. Nihal Atsız’ın yazılarını kendi yazım, davasını kendi davam biliyorum" demiştir (Goloğlu 1974: 248). Avukat İnce'nin sadece birkaç gün içinde Nihal Atsız ve davayla ilgili söylem değiştirmesi ve davadan çekilmesi, avukatın yakın zamanda Atsız ve diğer Turancı çevrelere yönelik başlatılacak operasyondan haberdar olduğu ve bu nedenle korktuğu için ya da zorla davadan çekildiği izlenimi vermektedir.

Ulus başyazarı Falih Rıfkı Atay 8 Mayıs tarihli yazısını da 3 Mayıs olaylarına ayırmıştır. "Niçin Üstünde Duruyoruz" başlıklı yazıda Atay, olayların basit bir zabıta vakası olduğunu yinelemiş; olaya fazla önem verdiği için değil, halkı bu fesatçı ve hileli oyunlara karşı uyarmak, tertemiz gençlerin sömürülmesine engel olmak amaciyla bu konu üzerinde durduğunu ifade etmiştir (8 Mayıs 1944). Atay'ın bu yazısı aynı gün Cumhuriyet (“Ulus'un Yeni Makalesi”, 8 Mayıs 1944) ve $A$ ş̧am ("Son tahrikçilik hadisesi münasebetile Ulus'ta bugün yeni bir makale neşredildi", 8 Mayıs 1944) gazetelerinde de yer almıştır.

9 Mayıs günü bütün gazetelerin başyazarları ağız birliği etmişçesine o günkü yazılarını Sabahattin Ali-Nihat Atsız davası çerçevesinde gelişen gösterilere ve ırkçılık-komünizm çatışmasına ayırmıştır. Söz konusu bu yazıların ortak vurgusu -Atay'ın yazılarında olduğu gibi- 3 Mayıs gösterilerinin basit ve önemsiz bir olaydan ibaret olduğu; bu gösterilere katılanların da aslında ırkçllık niyeti taşımayan, temiz niyetli, kandırılmış küçük bir grup genç olduğudur. Bütün gazete- 
ler tek bir noktadan emir almış gibi Türkiye'de ırkçılık diye bir ideoloji ve bu ideolojiye gönül vermiş kişiler olmadığını ispatlama çabasına girişmişlerdir.

Akşam gazetesi başyazarı Necmettin Sadak bu konuya ilk defa 9 Mayıs tarihli köşesinde yer vermiştir. Sadak, Anadolu halkının, Türk milletinin sağ nedir, sol nedir bilmediğini, bu ayrımların yabancı malı özentiler olduğunu dile getirmiş; ırkçılık, milliyetçilik, kızıl sosyalistlik, beynelmilelcilik gibi görüşlerin bulaşıcı bir hastalığın zayıf bünyelerde kolay yaşaması gibi ruhu zayıf, inançsız, boş kalmış ruhlarda yaşayabileceğini ifade etmiştir. Yazara göre yaşanan bu zabita olaylarında da bu buhranı görmek mümkündür. Sadak bu gösterilere katılanları da 'yaramaz çocuklar' olarak nitelemiş ve yazısını şu sözlerle sonlandırmıştır: "Să̆g, sol nedir bilmeyen Türk milleti, sağı solu yeni icat ettiğini sanan bu yaramaz çokluk çocuğun kulağını çeker" (Necmettin Sadak, "On ikiye beş kala”, Akşam, 9 Mayıs 1944).

Vakit başyazarı Asım Us 9 Mayıs'taki yazısında ırkçılık konusundan bahsetmiştir. Yazar temelde Sabahaddin Ali-Nihal Atsız davası etrafında gerçekleşen sokak gösterilerine istinaden yazdığı yazıda sadece ırkçı-sağ hareketlerden değil sol hareketlerden de şikayet etmiş, Türkiye'de ne sağ ne de sol aşırılıklara yer olmadığını dile getirmiştir. Aslında yaşananların ehemmiyetsiz olduğunu söyleyen yazar, gösterilere katılanlardan "Kemalizm nizamına bütün kalpleri ile bağh olduklarında şüphe olmayan bir kısım gençler" diye bahsetmektedir. Us da diğer yazarlar gibi nümayişe katılan gençlerin milliyetçilik kisvesi altında, nizam düşmanları tarafından kandırıldıklarını iddia etmektedir. Yazısında Falih Rıfkı Atay'ın Ulus'taki yazısına da atıfta bulunan ve onu destekleyen Asım Us "Türk gençliğini ve Türk efkarn umumiyesini doğru yoldan sağ veya sola saptırmak isteyenlerin anayasamızı ve milli mukaddesatımızı kendi ihtiraslarına alet için faaliyetlerine göz yumulamaz" diyerek ne sağ ne de sol hareketlere izin verilmeyeceğini yinelemiştir (Asım Us, "Vatanseverlik Maskesi Altında Sağ ve Sol İfratçılık", Vakit, 9 Mayıs 1944).

Tanin gazetesinden Hüseyin Cahit Yalçın da 9 Mayıs 1944 tarihli yazısını Sabahattin Ali-Nihal Atsız davası etrafında gerçekleşen sokak gösterilerine ayırmıştır. Gazetede söz konusu olaylarla ilgili hiçbir haber yer almamasına karşın başyazar Yalçın'ın konuya ilişkin doğrudan yorum yapması dikkat çekicidir. Yazar söz konusu yazıda Ankara'da yaşanan bu nümayişin bir aldatma ve tertip sonucunda gerçekleştiğini söylemektedir. Ülkedeki komünizm ve faşizm propagandasının, fikir hürriyeti çerçevesinde kabul edilebileceğini fakat eyleme geçtiği takdirde polisin görevini yapacağını ifade etmektedir. Faşizm, ne kadar Türkçülük, milliyetçilik gibi kelimelerle süslense, gizlense de onun temelinin zulüm ve istibdattan ibaret olduğunu söyleyen Yalçın, "Bugün bir Türk gencinin faşizm taraftarı olabilmesini düşündükçe tüylerimin ürperdiğini hissederim" demektedir (Hüseyin Cahit Yalçın, “Gençliğe Mal Edilmek İstenen Bir Hareket Hakkında", Tanin, 9 Mayıs 1944). 
Cumhuriyet başyazarı Nadir Nadi ise son olaylardan doğrudan bahsetmese de Cumhuriyet Halk Partisi'nin altı okundan biri olan milliyetçiliğin sınırlarının, yurdumuzun bir ucundan başlayıp diğer ucunda bittiğini hatırlatmaktadır (Nadir Nadi, “Bizim Realitemiz, Bizim İdealimiz!”, Cumhuriyet, 9 Mayıs 1944).

Falih Rıfkı Atay da Ulus'taki 9 Mayıs tarihli ve "Irkçılık ve Turancılık" başlıklı yazısında ırkçılığın Türkiye' yi içinden dağıtıp tahrip etmek için 1smarlanmış bir bela olduğunu ifade ederek yazısına şu cümlelerle devam etmiştir: "Irkçılık ve Turancılık, Anayasa prensiplerinin zıddıdırlar. Irkçı ve Turancı, Cumhuriyet Halk Partisinden olamaz. Irkçılar ve Turancılar, milli birliğin ve Türkiye emniyetinin tehlikesidirler. Bir Türkiye Türkçüsü ve Türkiye İstiklalcisiyiz." (Falih Rıfkı Atay, "Irkçılık ve Turancılık", 9 Mayıs 1944). Atay'ın bu yazısı aynı gün diğer ulusal gazetelerde de yer almıştır (Tan, "Ulus'un Makalesi", 9 Mayıs 1944; Tanin, "Irkçılık Masalı", 9 Mayıs 1944; Vakit, "Irkçılık ve Turancılık", 9 Mayıs 1944; Akşam, "Irkçılık ve Turancılık", 9 Mayıs 1944; Cumhuriyet, "Milli Birlik Düşmanı: Irkçı ve Turancı", 9 Mayıs 1944).

Sabahattin Ali-Nihal Atsız davasının son duruşması 9 Mayıs 1944'te yapılmıştır. İftiradan suçlu bulunan Nihal Atsız 4 ay hapis ve 66 lira para cezasına mahkûm edilmiş, ancak cezası ertelenmiştir.

\section{IRKÇILIK-TURANCILIK DAVASI}

Birbirinden bağımsız iki ayrı dava gibi görünmesine rağmen ırkçılık-Turancılık davası, Sabahattin Ali-Nihal Atsız davası etrafında gelişen olaylara paralel olarak başlamıştır. Nihal Atsız'ın Sabahattin Ali'ye hakaret etmek suçundan aldığı ceza ertelenmiş olsa da 3 Mayıs olayları gerekçe gösterilerek başta Nihal Atsız olmak üzere Turancılara yönelik yeni bir dava süreci başlatılmıştır.

\subsection{Gözaltı ve Tutuklamalar}

9 Mayıs'ta davası sona eren Nihal Atsız Ankara'dan İstanbul'a dönmeye hazırlandığı ertesi gün Ankara'da kaldığı otelde tutuklanmıştır. Atsız'ın tutuklanmasını başka tutuklamalar takip etmiştir. 3 Mayıs gösterilerinin sorumlusu olarak görülen ve Turancı çevrelerde yer alan kişilerin evleri aranmış, tutuklamalar yapılmıştır. Tutuklananlar arasında Nejdet Sançar, Zeki Velidi Togan, Reha Oğuz Türkkan, Hasan Ferit Cansever, Nurullah Barıman, Orhan Şaik Gökyay'ın, Hamza Sadi Özbek gibi isimler yer almaktadır.

Bu süreçte ulusal gazeteler irkçılık-Turancılık konusunda yayın yapmaya devam etmişlerdir. Ulus'tan Falih Rıfkı Atay 13 Mayıs tarihli yazısında "'- Biraz sağdırlar ama ne çıkar, koyu milliyetçidirler!' diye sütunlarımızda, konferans salonlarımızda yer verdiğimiz, yayın ve toplantı vasıtalarımızdan faydalanmaların hoş gördüğ̈̈müz sözde bir fikir hareketi üstüne artık tam bir teşhis koymuş bulunuyoruz." diyerek Turanc1 
harekete müsamaha gösterdiklerini kabul etmektedir. Turanc1 hareketten "iyi niyetleri, milli denen her şeye derinden bağglilı̆̆ gafil avlamă̆a, alttan alta Anayasa nizamın yıkmağa çalışan, içerde bir faşist diktatoryası kurmă̆a ve ham hayaller uğruna, bu memleketi dişarda bin türlü sergüzeştçiliğe alet etmeğge savaşan, kökleri, dal budakları ile Romanya'daki Gardistlikten farksız, firsat gözleyici bir teşkilatlanmadır" diye bahsetmektedir (Falih Rıfkı Atay, "Biz Tek Bir Cepheyiz", Ulus, 13 Mayıs 1944). Atay bir başka yazısında da "Türkiye Türkleri, Anayasaya ve Cumhuriyet Halk Partisinin temel prensiplerine göre nasyonalist milliyetçidirler. Ne Turancl, ne de ırkçıdırlar. Turancılık dış politika bakımından, müstakil Türkiye'nin nasıl başlıca tehlikelerinden biri ise, ırkçılık, iç politika bakımından 'bir ve bütün Türkiye'nin parçalanmasından, azalıp dağglmasından başka hiçbir işe yaramaz" diyerek Türkiye'de irkçı ve Turancı görüşlere yer olmadığını ifade etmiştir (Falih Rıfkı Atay, "Hak Görünüründe Bir Kayg1", Ulus, 18 May1s 1944).

Vakit başyazarı Asım Us'un 10 Mayıs tarihli yazısı da ırkçlık-Turancılık konusuna ayrılmıştır. Tıpkı Panislamizm gibi Pantürkizm'in ve Turancılığın Osmanlı İmparatorluğu'yla birlikte sona erdiğini anlatan yazar, Türkiye Cumhuriyeti’ndeki Türkçülük anlayışıyla Turancılığın aynı şey olmadığını ifade etmiştir. Us yazısında, 'zavallı öğretmen' diye bahsettiği Nihal Atsız'ın, tarihe karışmış Turancılık akımını yeniden gündeme getirmek suretiyle kendisine siyasi bir mevki edinmek hevesine düştüğünü, bunu yaparken de henüz tahsil çağında olan gençleri kendi ihtiraslarına alet ettiğini yazmaktadır (Asım Us, "Türkçülük Fikrinin Tarihi Tekamülünde Kargaşalık", Vakit, 10 Mayıs 1944).

16 Mayıs tarihli başyazısında son olaylara değinen Akşam başyazarı Necmettin Sadak, bu asırda ırkçılığın yeri olmadığını, ırkçılığın demokrasinin yani hak ve görev eşitliğinin düşmanı olduğunu yazmıştır. Sadak, yaşanan sokak olaylarının ve gösterilerin her zaman yaşanabilecek sıradan şeyler olduğunu; zabita kuvveti ve devlet otoritesiyle kolaylıkla üstesinden gelinebileceğini ifade ederek hem olayları basit bir asayiş meselesi olarak nitelendirmiş, hem de devletin gücüne vurgu yapmıştır. Diğer yandan yazara göre asıl şaşırtıcı olan ve üzerinde durulması gereken sorun, okumuş ve eğitimli üniversiteli gençler arasında bu tür devri geçmiş ideolojilerin kabul görmesi ve yaygınlık kazanmasıdır. "Bu duruma engel olmak başlıca vazifemizdir" diyen Sadak yazısını şu cümlelerle sonlandırmıştır: "Bu millet ne beynelmilelcilik, ne Íslamcilık, ne Turancilık cezbelerine kurban edilmeyecektir. Milli idealimiz Türkiye Cumhuriyeti'ni yükseltmektir." (Necmettin Sadak, "Bu Asırda Millet ve Milliyet Seciyesi Halis Kan Yarış Atı Evsafına Benzemez", Akşam, 16 Mayıs 1944).

Necmettin Sadak 17 Mayıs tarihli yazısında da aynı konuya değinmiştir. Din ve millet rengine boyanmış, yerli malı gibi görünen fakat kökleri dışarıda olan ırkçılık, İslamcılık, Turancılık gibi ideolojilere karşı uyanık olmak ve gençliği bunlardan korumak gerektiğini ifade etmektedir. Yazar, bütün dünyanın bir buhran 
yaşadığı, salgına elverişli bu dönemde ruhların ve fikirlerin bir boşluk içinde olduğu; rrkçılık gibi ideolojilerin de bu boşluktan faydalandı̆̆ı görüşündedir (Necmettin Sadak, "Gençliği Koruyalım”, Akşam, 17 Mayıs 1944)

Hüseyin Cahit Yalçın, konuyla ilgili bir yazısında o günün Türkiye'sinde Türklük esasına dayanan bir milliyetçiliğin olmadığını açıklamak üzere Cumhuriyet döneminde Türkçülüğün vatanseverlikten ve ülkesinin refahı ve mutluluğu için çalışmaktan başka bir anlam taşımadığını; Türkçülüğün Osmanlı dönemine ait bir ideoloji olduğunu ifade etmiştir (Hüseyin Cahit Yalçın, "Bizde Türkçülük", Tanin, 18 Mayıs 1944). Yalçın “Turancılık Hareketi” başlıklı bir başka yazısında da bütün Türkleri tek bir bayrak ve tek bir yönetim altında toplama fikrine dayanan Turan idealinin Osmanlı'nın son dönemlerinde kaldığını, Türkiye Cumhuriyeti'nin kurulmasıyla tamamen ortadan kalktığı yinelemiştir. Böyle bir idealin ne kadar anlamsız bir hayal olduğunu ve mümkün olamayacağını açıklayan yazar özellikle Sovyetleri kastederek komşularımızın şüphelerini ve düşmanlıklarını tahrik etmenin fayda getirmeyeceğini, yakın doğuda barış, sükûnet ve istikrarın ülkenin en büyük menfaatlerinden biri olduğunu ifade etmiştir (Hüseyin Cahit Yalçın, "Turancılık Hareketi”, Tanin, 19 Mayıs 1944).

Tan başyazarı Zekeriya Sertel de ırkçılık-Turancılık konusuna değindiği 10 Mayıs tarihli yazısında Falih Rıfkı Atay gibi son dönemde gündeme gelen ırkç-Turancı hareketi, Romanya'daki Gardist harekete benzetmiştir. Gardistlerin Romanya'ya verdiği zararları anlatan yazar, bu iki durumun benzerliğine dikkat çekmiş ve Romanya örneğinden ders almak gerektiğini belirtmiştir. Turancılığı dışarıdan gelen yabancı bir ideoloji olarak niteleyen Sertel saf ve gafil gençleri kandırarak ülkeyi felakete götürmek istediğini ifade etmiştir (M. Zekeriya Sertel, "Türk Gençliğine Yakın Tarihten Bir İbret Levhası", Tan, 10 Mayıs 1944).

18 Mayıs'ta bir resmi tebliğ yayımlanarak Nihal Atsı-Sabahaddin Ali davası sırasında Atsız lehine yapılan taşkınlıklar sonucu gözaltına alınan kimselerden elde edilen belgelerin verdiği şüphe üzerine Nihal Atsız, Reha Oğuz Türkkan, Zeki Velidi ve Hasan Ferit Cansever' in evlerinde İstanbul Sıkıyönetim Komutanlığı'nca arama yapıldı $\breve{g}$ bildirilmiştir. Aramalarda elde edilen belgelerin incelenmesi sonucunda, ırkçılık ve Turancılık amacı güden ve son zamanlarda faaliyetlerini artırdıkları, bu yolda tertibat aldıkları görülen bu kimselerin, Anayasa'ya, rejime ve vatandaşların hakiki milliyetçilik hislerine aykırı amaçlara ulaşmak için gizli cemiyetleri, teşkilât ve propaganda organları, hatta muhaberelerini gizli tutmak için özel şifreleri ve parolaları olduğu; memleketin çeşitli bölgelerinde ve her türlü eğitim kurumunda masum gençlerin milliyetçilik ve vatanseverlik duygularını istismar ederek genç nesil arasında kendilerine taraftar toplamak ve bu sayede hedeflerine ulaşmak için devamlı ve sistemli bir faaliyette bulundukları; bu faaliyetler Anayasa ve Türk Ceza Kanunu'na göre suç sayıldı̆̆ı 
için adlî merciler tarafından kanunî takibat yapılmak üzere işe el konulduğu açıklanmıştır (Ayın Tarihi Mayıs 1944: 21).

Anadolu Ajansı aracılığıyla yayımlanan bu resmi tebliğ incelenen gazetelerde geniş yer bulmuştur (Ulus, "Son Tahriklerin Gizli Bir Cemiyetin Eseri Olduğu Anlaşıldı", 19 Mayıs 1944; Tanin, "Türk Gençliğini İstismar Edenler", 19 Mayıs 1944; Tan, "Tahrikçiler Meydana Çıkarıldı", 19 Mayıs 1944; Cumhuriyet, "Şehrimizde Meydana Çıkarılan Gizli Cemiyet, 19 Mayıs 1944; Vakit, “Gizli Teşkilat Kuranlar Adliyeye Verildiler", 19 Mayıs 1944; Akşam, "Gizli Bir Teşkilat Meydana Çıkarıldı", 19 Mayıs 1944).

Bu tebliğin ertesi gün Cumhurbaşkanı İsmet İnönü, 19 Mayıs Gençlik ve Spor Bayramı nedeniyle verdiği nutukta bu konuya da geniş yer vermiş, Türkiye'de ırkçılık ve Turancılık gibi fesatçı ideolojilere yer olmadığını açıklamıştır:

Türk milliyetçisiyiz, fakat ülkemizde ırkçılık prensibinin düşmanıyız...

Turancılar, Türk milletini bütün komşularıla onulmaz bir surette derhal düşman yapmak için birebir tılsım bulmuşlardır. Bu kadar bilinçsiz ve vicdansız bozguncuların yalan dolanlarına Türk milletinin mukadderatın kaptırmamak için elbette Cumhuriyetin bütün tedbirlerini kullanacağız. Bozguncular genç çocuklarn ve saf vatandaşları aldatan düşüncelerini millet karşısında açıktan açı̆̆a tartışmayacağımızı sanmışlardır. Aldanmışlardır ve daha çok aldanacaklardır... Vatandaşlarım! Emin olabilirsiniz ki, vatanımızı bu yeni fesatlara karşı da kudretle müdafaa edeceğiz (Ayın Tarihi Mayıs 1944: 27-29).

İnönü nutkunda Turancılık fikri etrafında Türkiye'nin diş politikasına da değinmiş, "Milli Kurtuluş Savaşı sona erdiğinde tek dostumuz Sovyetlerdi" diyerek Sovyetler Birliği'nin Türk dış politikası açısından önemli olduğunu ima etmiştir. İnönü "Görülüyor ki milli politikamız memleket dışında sergüzeşt aramak zihniyetinden tamamen uzaktır; asıl mühim olan da bunun bir zaruret politikası değil, bir anlayıs ve bir inanç politikası olmasıdır." sözleriyle Türkiye'nin ülke sınırları dışındaki Türkleri birleştirmek gibi bir amacının olmadığının altını çizmiştir. Aslında İnönü bu nutukla bir yandan Türk gençliğine seslenirken bir o kadar da Sovyet yöneticilerine seslenmiştir (8).

Turancılara yönelik operasyonla ilgili olarak kamuoyunu asıl yönlendiren ve sanıkların daha mahkeme önüne çıkmadan neredeyse kesin suçlu sayılmasına yol açan etken hükümetin 18 Mayıs tarihli genelgesinden çok, İsmet İnönü'nün 19 Mayıs konuşması olmuştur (Özdoğan 2002: 109). Çünkü İsmet İnönü 19 Mayıs nutkunda, henüz mahkemece suçları kesinleşmemiş kimseleri kamuoyu nezdinde direkt suçlu ilan etmiştir. Aynı suçlayıcı tavır dönemin yazılı basınında da açıkça görülmektedir. 
Falih Rıfkı Atay 21 Mayıs tarihli başyazısını İsmet İnönü'nün nutkuna ayırmış, özellikle ırkçılık ve Turancılık konusunda Milli Şef'i destekleyen ifadelere yer vermiştir (Falih Rıfkı Atay, "Cumhurreisimizin Nutku”, Ulus ,21 Mayıs 1944). Atay'ın bu yazısı Vakit ve Tan gazetelerinde de aynı gün yayımlanmış, Atay'ın makalesinden bazı bölümlere yer verilmiştir (Vakit, "Milli Şefin Nutku Yüklü Bulutları Dağıttı”, 21 Mayıs 1944; Tan, “Ulus'un Makalesi”, 21 Mayıs 1944).

M. Zekeriya Sertel de 21 Mayıs tarihli yazısını bu konuya ayırmıştır. Cumhurbaşkanı İsmet İnönü'nün 19 Mayıs nutkunda konuyla ilgili söylediklerinden kesitler veren ve bunları destekleyen yazar "Cumhurreisimiz İönü, 19 Mayıs bayramı münasebetiyle gençliğe hitaben verdikleri demeçte, mütehassls bir doktor gibi hastalı̆̆ teşhis etmiş, vahametini ve tehlikelerini anlatmış ve tedavi usullerini göstermiş̧ir" sözleriyle uzun yıllar boyunca müsamaha gösterilen ve gerçek yüzünü gizlemeyi başaran bu ırkçı teşkilatın İnönü tarafından ifşa edildiğini dile getirmiştir (M. Zekeriya Sertel, "Cumhurreisimizin Gençliğe Hitabesi Hakkında”, Tan, 21 Mayıs 1944).

İsmet İnönü'nün 19 Mayıs nutku Tanin' de “Cumhurreisimizin Dünkü Nutukları” başlığıyla duyurulmuş, haberin girişinde de "Türk gençliğini öven Milli Şef, Irkçllı ve Turancılık maskesi altında fesat çıkarmă̆a çalışanları şiddetle takbih etti" denilerek İnönü'nün ırkçlık ve Turancılık konusunda söyledikleri öne çıkarılmıştır (Tanin, "Cumhurreisimizin Dünkü Nutukları", 20 Mayıs 1944). Ayrıca gazetenin başyazarı Hüseyin Cahit Yalçın da aynı gün yazısında İnönü'nün 19 Mayıs nutkundan bahsetmiştir. İnönü'nün sözlerine övgüler dizen yazar, özellikle ırkçılık ve Turancılık konusunda Milli Şef'in halkın içini rahatlattığını ve güven verdiğini şu cümlelerle ifade ermiştir:

Dünyanın bugünkü emsalsiz buhranı arasında Türk vatanını selamete çıkarmak için hemen hemen beş seneden beri sarf edilmiş muvaffakiyetli gayretleri baltalamak ister gibi tam şu sırada şahit olduğumuz ırkçılık ve Turancilık meseleleri yüzünden bütün memleketi kaplamış olan sinirlilik ve üzüntü Milli Şef'in ruhlara nüfuz edici sözleriyle silinip kalkmış oluyor. Memleket şu dakikada bu sesi dinlemeğe muhtaçtı. Henüz bütün mahiyeti ile aydınlatılmamış bir vakanın mevcudiyeti zihinlerde müphem ve bittabi mübalağalı telakkilere yol açmak imkanını verirken Milli Şef'in tam vaktinde yetişen ihtar ve irşadı düşmanların umdukları karışıklık ve ayrılığın önünü aldı (Hüseyin Cahit Yalçın, "Milli Şefin Gençliğe Hitabesi", Tanin, 20 Mayıs 1944).

Cumhurbaşkanı İsmet İnönü'nün 19 Mayıs nutku, ertesi gün $A$ ş̧am'da tam sayfa yer almıştır. "İsmet İnönü'nün Türk Gençliğine Tarihi Nutku" başlıklı haberin girişinde İnönü'nün ırkçılık-Turancılık davasıyla ilgili şu ifadesi ön plana çıkarılmıştır: "Türk milliyetçisiyiz, fakat memleketimizde ırkçılık prensibinin düşmanıyız, Turancılık zararlı bir gösteridir" (Akşam, "İsmet İnönü'nün Türk Gençliğine Tarihi 
Nutku", Akşam, 20 Mayıs 1944). Başyazar Necmettin Sadak ise 21 Mayıs tarihli yazısında bu konuya değinmiştir. Nutuktan "Cumhurreisinin, dinlediğimiz ve birkaç defa da zevkle istifade ile okuduğumuz son nutku, zamanın bu çetin fikir dava ve polemikleri bahsinde, her yerde ve her dilde dinleyip okuduklarımızın en güzeli, en kuvvetlisi, ruhu en çok çekenidir. En tesirli, en kolay akılda tutulacak bir ders gibi, bu nutku her vasıta ile her yere yaymak, herkese okutmak lazımdır." şeklinde övgüyle bahseden Sadak, İnönü'nün ırkçılık konusundaki açıklamalarını desteklemekte, ırkçılığın Türkiye'yi içinden, Turancılığınsa dışından yıkmak için bulunmuş en verimli tedbirler olduğunu dile getirmiştir (Necmettin Sadak, "Milli Şefin Millete Büyük Dersi", Akşam, 21 Mayıs 1944).

Cumhuriyet gazetesi İsmet İnönü'nün 19 Mayıs nutkuyla ilgili haberinde İnönü'nün son yaşanan olaylar ve ırkçlık-Turancılık konusundaki ifadeleri ön plana çıkarmıştır. Manşetten yayımlanan haberin girişinde İnönü'nün “Vatanımızı ırkçı ve Turancıların fesatlarına karşı da kudretle müdafaa edeceğiz", "Milli politikamız memleket dışında sergüzeşt aramak zihniyetinden uzaktır" ifadelerine yer verilerek hem konunun Cumhurbaşkanı için taşıdığ ye'nin Turancı amaçlar gütmediği ve Sovyetler Birliği'nin topraklarında gözü olmadığı vurgulanmıştır (Cumhuriyet, "Milli Şefin Tarihi Nutku”, 20 Mayıs 1944).

Irkçllık-Turancılık operasyonunda tutuklamaların sürdüğü ve henüz hala yarg1lama aşamasına bile geçilmediği günlerde ulusal gazeteler konuyla ilgili kesin hüküm içeren ve suçlayıcı yayınlarına devam etmişlerdir. Özellikle sol yayın çizgisiyle bilinen Tan gazetesi konuya günlerce geniş yer ayırmıştır. Gazetede 21 Mayıs'tan itibaren "Kendi Ağılarından İç Yüzleri" başlıklı bir yazı dizisi yayımlanmaya başlamıştır. Son olaylarda gözaltına alınan ve evlerinde arama yapılan Nihal Atsız, Reha Oğuz Türkkan ve Zeki Velidi'nin milliyetçilik maskesi altındaki 'iç yüzlerini' ortaya koymayı amaçlayan bu yazı dizisinde söz konusu şahıslar hakkında bilgi verilmiş, birbirleri hakkında ne düşündüklerine dair kendi yazılarından alıntılar aktarılmıştır. Ayrıca bu isimlerin, Türkiye merkezli bir Turan devleti kurmak için gerçekleştirmeyi planladıkları programları da yayımlanmıştır. Yazı dizisinin birinci bölümünde şöyle denilmiştir:

Bu asi mahlûkların, ne yapmak istediklerini, biz, kendiliğimizden anlatmak istemiyoruz. Onların, muhtelif tarihlerde kapatılan, Eyüplü Halit gibi, isim değiştire değiştire tekrar çıkan mecmuaları, kitapları, risaleleriyle bugün yakalarına memleketi batırmă̆a yeltenmek rozeti takılmış olan Nihal Adsız ve Reha Ŏ̆uz Türkkanın, birbirleri aleyhine yaptıkları neşriyatı mehaz tutuyor, bu nankör, bu mayasıll, işkilli ve dingildiyen kafaların birbirleri hakkındaki laflarım aynen yazıyoruz (Tan, "Nihal Adsız Kimdir?", 21 Mayıs 1944). 
Yazı dizisinin 22 Mayıs'ta yayımlanan “Adsız'ın Kim Olduğunu Reha Oğuz Anlatıyor” başlıklı bölümünde Reha Oğuz Türkkan'ın 'Kuyruk Acısı' isimli broşüründe yakın arkadaşı Nihal Atsız hakkında yazdıklarına yer verilmiştir. Türkkan, Atsız'dan bahsederken onun için zayıf, dengesiz, kıskanç gibi ifadeler kullanmış, çevresinde pek sevilmeyen bir kişi olduğunu anlatmıştır (Tan, “Adsız'ın Kim Olduğunu Reha Oğuz Anlatıyor", 22 Mayıs 1944). Yazı dizisinin Reha Oğuz Türkkan'la ilgili üçüncü bölümünde ise Türkkan hakkında şunlar söylenmiştir:

Reha Oğuz Türkkan, hakiki bir bulanık hava firsatçısıdır. Şimdiye kadar neşrettiği kitap, broşür, risale ve mecmualarla, bir numaralı akıl karıştırıcı olduğunu ortaya koymuştur. Kendini, daima olduğundan büyük göstermek, bu suretle gözleri kamaştırmak isteyen Reha Oğuz, icap ettiği anda, yalan söylemekten bile çekinmez (Tan, "Reha Oğuz Türkkan İçin Ne Diyorlar?", 23 Mayıs 1944).

Tan yazarlarından Refik Halid Karay da konuya ilişkin kaleme aldığı bir yazısında Türk milliyetçiliğini, Türkiye'yi benimsemiş, kültürünü sindirmiş, bayramlarında yüreği neşeden taşan, yaslarında gönlünü elem kaplayan, iyiliğine candan sevinen, Türkiye'nin en ileri bir memleket olmasını isteyen bütün vatandaşların iş ve ideal birliği olarak tanımlamış; son olaylarda gözaltına alınanlarla ilgili olarak da şunları söylemiştir: "Memleketi kan tahlilleriyle kana boyayıp neticede kansız bırakmak isteyenlerin ve Türk vatandaşının suratına ırk bahanesiyle vatanseverlik kapılarını örtmeğe yeltenenlerin asıl şimdi kendileri, millî adaletin üzerlerine kilitlediği kapının arkasındadırlar. Şüphesiz ki dünkü kan arayıclarının bugün kendi yüzlerinde korkudan bir damla kan kalmamıştır" (Refik Halid Karay, "Kan Tahlillerile Kana Boyanıp Kansız Kalacak Vatan!", Tan, 21 Mayıs 1944).

Vakit başyazarı Asım Us Nihal Atsız, Reha Oğuz Türkkan, Zeki Velidi Togan gibi isimlerin Turan gizli cemiyeti kurarak dost maskesi altında cumhuriyet rejimine saldırmayı planladıklarını yazmıştır. Ülkede komünist tehlikesi varmış gibi gösterip sahte planlarıyla 5-10 küçük mektep çocuğunu ve genci aldatmış olsalar da milleti kandıramayacaklarını ifade etmiştir (Asım Us, "Gizli Turan Cemiyeti Şeklinde Bir Fesat Şebekesi", Vakit, 25 Mayıs 1944). Us, bir başka yazısında ise Turancıların 'Türkçülük kalpazanlığı' yaparak milletin milli duygularını iğfal ettiklerini dile getirmiştir (Asım Us, "Ne Mutlu Türküm! Diyenler Azaldı mı? Yoksa Çoğaldı mı?, Vakit, 30 Mayıs 1944).

Hüseyin Cahit Yalçın Türkiye'deki Turancılık hareketinde ve son olaylarda Nazi Almanya'sının rolü olduğunu iddia etmiştir. “Bizde ırkçılık idealini temsil ederek ortaya çıkmış olanların Nazilere has zahiri alametleri, tavır ve hareketleri bile aynı aynına taklit ve tatbik etmeleri yalnız bir tesadüf eseri midir, değil midir?" diye soran yazar Almanların pençelerini geçirmek istedikleri ülkelerde birtakım milli ihtiraslar 
uyandırıp, bu amaç doğrultusunda taraftar toplamak gibi bir gelenekleri olduğunu ve bunu pek çok ülkede de uyguladıklarını ifade etmiştir (Hüseyin Cahit Yalçın, "Irkçılık ve Turancılık Tahriklerinde Nazilerin Rolü Var mıdır?", Tanin, 22 Mayis 1944).

\subsection{Dava Süreci}

Irkçılık-Turancılık davasının ilk duruşması 7 Eylül 1944 tarihinde yani tutuklamalardan yaklaşık 3,5 ay sonra görülmeye başlamıştır (9). Soruşturmalar sonunda şu 23 ismin mahkemeye verilmesi kararlaştırılmıştır: Zeki Velidî Togan, Hasan Ferit Cansever, Hüseyin Nihal Atsız, Alparslan Türkeş, Nejdet Sançar, Fethi Tevetoğlu, Orhan Şaik Gökyay, Reha Oğuz Türkan (10), Hüseyin Namık Orkun, Sait Bilgiç, M. Zeki Özgür, İsmet Tümtürk, Hikmet Tanyu, Hamza Sâdi Özbek, Muzaffer Eriş, Cebbar Şenel, Nurullah Barıman, Cihat Savaşfer, Fazıl Hisarcıklı, O. Yusuf Kadıgil, Fehiman Altan, Cemal Oğuz Öcal, Saim Bayrak.

Mayıs ayında başlatılan aramalar ve gözaltılar ülke çapında yapılmış olmasına karşın, gözaltına alınanların hepsi o dönemde sıkıyönetim sınırları içinde olan İstanbul'a sevk edilmiştir. Bu nedenle davaya Birinci Sıkıyönetim Mahkemesi bakmıştır. 7 Eylül tarihli ilk duruşmada Sıkıyönetim Komutanlığı Savcısı Kazım Alöç'ün hazırladığı iddianameye göre sanıklar hakkında 18 Mayıs 1944 tarihli hükümet bildirisinde belirtilen suçlamaların yanı sıra genel olarak hedeflerine ulaşmak için devamlı ve sistemli bir faaliyet sarf etmek ve memlekette zararlı ideolojilerini tahakkuk ettirmek yolunda muhtelif gruplar halinde çalışmak, memleket aleyhine bu gizli cemiyetleri kendi maksatlarına göre tevcih etmek isteyen yabancı teşekküllerle fesat ve ihanet içinde olmak, hükümeti devirmek için cemiyet kurmak, hükümetin Büyük Millet Meclisi'nin manevi şahsiyetlerini tahkir, milli menfaatlere muhalif hareket etmek, gayesi devletin Teşkilatı Esasiye Kanunu ile muayyen olan ana vasıflarına muhalif milli hissiyatı sarsmaya zayıflatmaya matuf propaganda yapmak suçlamaları da yapılmıştır (Özdoğan 2002: 110-111).

Görüldügü üzere sanıklar gizli örgüt kurmak suretiyle hükümeti devirmeye teşebbüs etmek yani darbe yapmakla suçlanmışlardır. Darendelioğlu'na göre (1968: 51) bu davanın bambaşka bir yöne çekilmesi ve bir hükümet darbesi gibi gösterilmesi Maarif Vekili Hasan Ali Yücel, Ankara Valisi Nevzat Tandoğan ve Ulus gazetesi başyazarı Falih Rıfkı Atay'ın marifetiyle gerçekleşmiştir.

2 Şubat 1945 günü gerçekleştirilen duruşmada Sıkıyönetim Savcısı Kazım Alöç, Irkçllık-Turancılık davası kapsamında Nihal Atsız, Zeki Velidi Togan, Reha Oğuz Türkkan, Cihad Savaşer, Nurullah Barıman ve arkadaşları hakkında hazırladığ1 iddianameyi okumuştur. Duruşma Akşam gazetesinde "Irkçıların Muhakemesi" başlı̆̆ıyla verilmiştir. Haberin girişinde Savcı Alöç'ün iddianamesinden şu ifadeler aynen aktarılmıştır: “Bu ırkçı ve Turancı adamlar kendilerine 'Türkçüler' 
bugünkü rejimimizi benimseyen kendilerinden ayrı kütleye 'Atatürkçü' demektedirler" (Akşam, "Irkçıların Muhakemesi", 3 Şubat 1945). Duruşma Tanin gazetesinde de yer almış, haberin girişinde "Dün suçlular hakkında iddianame okundu" denilerek sanıklar doğrudan 'suçlu' ilan edilmiştir. Savcı Alöç'ün mahkemeye sunduğu iddianame gazetede tam sayfa ayrıntılı bir biçimde yayımlanmıştır (Tanin, "Irkçıların Duruşması", 3 Şubat 1945). Haber Ulus, Cumhuriyet ve Vakit gazetelerinde de yer almış, savcı iddianamesi aynen yayımlanmıştır (11). İncelenen gazetelerin hepsi, henüz suçları kesinleşmemiş olmasına karşın sanıklar hakkında 'ırkçı' tanımlamasını kullanmışlardır (Ulus, "Irkçıların Davası Son Safhasında", 3 Şubat 1945; Cumhuriyet, "Irkçılar İçin İstenen Cezalar", 3 Şubat 1945; Vakit, "Irkçıların Muhakemesi", 3 Şubat 1945).

Dava 29 Mart 1945 tarihli duruşmada sonuçlanmış, 23 sanıktan 13'ü beraat ederken 10'una çeşitli cezalar verilmiştir. Karara göre Nihal Atsız 4 yıl 3 ay 15 gün hapis ve 3 yıl Adana'ya sürgün cezasına, müebbeten amme hizmetlerinden mahrumiyetine; Zeki Velidi Togan 10 yıl hapis ve 4 yıl Adapazarı'na sürgün cezası, müebbeten amme hizmetlerinden mahrumiyetine; Reha Oğuz Türkkan 5 yıl 5 ay hapis ve 2 yıl Diyarbakır'da sürgün cezasına, müebbeten amme hizmetlerinden mahrumiyetine; Cihad Savaşer 4 yıl hapis ve 1,5 yıl Uşak'ta sürgün cezasına, 4 yıl amme hizmetlerinden mahrumiyetine; Nurullah Barıman 4 yıl hapis ve 1,5 yıl Kırşehir'de sürgün cezasına, 4 yıl amme hizmetlerinden mahrumiyetine; Necdet Sancar 1 yıl iki ay hapis cezasına; Alpaslan Türkeş 9 ay 10 hapis cezasına; Fethi Tevetoğlu 11 ay gün hapis cezasına; Cebbar Şenal ve Cemal Oğuz Öcal 11 'er ay hapis cezasına mahkûm edilmiştir. Son duruşma incelenen gazetelerin hepsinde geniş yer almıştır (Akşam, "Irkçılar Hakkındaki Karar", 30 Mart 1945; Vakit, "Irkçılar Hakkında Karar Verildi", 30 Mart 1945; Tanin, "Irkçılar Hakkında Sıkı Yönetim Mahkemesi Kararını Verdi, 30 Mart 1945; Ulus, "Irkçıların Davası Karara Bağlandı", 30 Mart 1945; Cumhuriyet, "Irkçıların Davası Bitti", 30 Mart 1945; Tan, Irkçllar Hakkında Dün Karar Verildi, 30 Mart 1945).

Mart ayında görülen karar duruşmasından yaklaşık yedi ay sonra ırkçllıkTurancılık davasıyla ilgili yeni bir gelişme yaşanmıştır. 23 Ekim 1945'te Askeri Yargıtay, Birinci Sıkıyönetim Mahkemesi'nin 29 Mart tarihli kararını bozmuştur. Davanın İkinci Sıkıyönetim Mahkemesi tarafından yeniden görülmesine karar verilmiş ve bütün sanıklar 26 Ekim 1945 tarihinde tahliye edilmişlerdir.

Askeri Yargıtay'ın kararı bozma haberi Vakit gazetesinde "Irkçılık Sanıkları Hakkındaki Karar Bozuldu" (25 Ekim 1945) ve "Irkçılık Sanıkları" başlıklarıyla duyurulmuştur (26 Ekim 1945). Her iki haberin hem başlığında hem de içeriğinde 'ırkçılar' ifadesi yerine 'ırkçılık sanıkları' ya da 'sanıklar' ifadeleri tercih edilmiştir. Aynı haber Tanin'de "Irkçılık ve Gizli Cemiyet Kurmaktan Maznun Olanlar" başlığıyla verilmiş, dava dosyasının İkinci Askeri Mahkeme'ye verildiği ve davanın bu mahkeme tarafından yeniden görüleceği bildirilmiştir (Tanin, "Irkçılık 
ve Gizli Cemiyet Kurmaktan Maznun Olanlar", 25 Ekim 1945). Vakit gazetesi gibi Tanin gazetesi de haberde 'maznun' yani sanık kelimesini tercih etmiştir. Cumhuriyet gazetesi bu son gelişmeyi "Irkçılar Tahliye Ediliyorlar" başlığıyla duyururken (26 Ekim 1945) Ulus ve Akşam gazetelerinde konuya ilişkin haber yayımlanmamiştır.

Davaya 26 Ağustos 1946 tarihinde İkinci Sıkıyönetim Mahkemesi'nde tekrar başlanmış, 31 Mart 1947'de sanıkların tamamının beraat etmesiyle dava sonlanmıştır. Mahkeme, ırkçılığın Anayasa'ya aykırı bir fiil olduğu, fakat Türk Ceza Kanunu'nda bunu cezalandıran bir hüküm olmadığından sanıkların beraatine karar vermiştir.

Davanın en başından beri sanıklar hakkında oldukça sert ve suçlayıcı bir üslupla yayın yapan ve davadan da 'irkçılık davası' diye bahseden; hatta bu anlamda diğer ulusal gazeteler için kanaat önderi olan Ulus gazetesi, bu yeniden yargilama sürecinde davadan 'Turancilık davası' diye bahsederken, sanıklar için de 'Turancılar' tanımlamasını kullanmıştır (Ulus, “Turancılık Davası”, 27 Ağustos 1946; "Turancılar Davası Sona Erdi", 1 Nisan 1947). Benzer şekilde Akşam ve Vakit gazeteleri de bu süreçte 'Turancılar', 'sanıklar' gibi daha ılımlı ifadeler kullanmışlardır (Akşam, "Turanciların Muhakemesi, 27 Ağustos 1946; Vakit, "Irkçllıktan Sanık Bulunanların Muhakemesi", 27 Ağustos 1946; Vakit, "Irkçılık Sanıkları Beraet Ettiler", 1 Nisan 1947).

\section{SONUÇ VE DEĞERLENDİRME}

'Irkçılık-Turancılık davası' dönemin uluslararası konjonktürüne ve Türk dış politikasına bağlı olarak ortaya çıkmış ve gelişmiş siyasi bir dava olmanın yanı sıra birçok açıdan adaletsizliği ve usulsüzlüğü de bünyesinde barındıran hukuki bir süreçtir. İkinci Dünya Savaşı'nın özgül koşulları içerisinde Türk hükümetinin Turancı akıma karşı tutumu, savaşın seyrine ve ortaya çıkabilecek ihtimallere göre değişiklik göstermiştir. Bu çerçevede ırkçılık-Turancılık davasının ortaya çıkışı, seyri ve sonuçlanma süreci de Türk-Alman ve Türk-Sovyet ilişkileri ekseninde gelişmiştir.

Almanya'yla kurulan dostane ilişkiler ve Almanya'nın savaşta sağladığı galibiyetler bağlamında 1943 yılının sonlarına kadar resmî ideoloji tarafından hoşgörüyle karşılanan hatta hükümet çevrelerinde bizzat destek bulan Turancı hareketin 1944 yılının başlarından itibaren tasfiye edilmesi, bir taraftan Almanya ile diplomatik ilişkilerin sona erdiğini Müttefiklere göstermede atılan adımlardan biri olarak kabul edilirken diğer taraftan Türkiye savaşa girmediği için soğuyan Türk-Sovyet ilişkilerini ısıtmak için akıllıca yapılmış bir plan olarak değerlendirilebilir. 
Berkes'e göre (2005) 1rkçllık-Turancılık davası, savaşın sonunda Milli Şef İsmet İnönü'nün eşsiz zekâsıyla kendini ve partisini Turancılık hareketinin dışında gösterebilmek için kurguladığı bir komplodur. Turancılık hareketi Von Papen'den İsmet İnönü'ye Şükrü Saraçoğlu'ndan Mareşal Fevzi Çakmak'a kadar pek çok kişinin bilgisi ve desteğiyle gelişmiş olmasına karşın olaylar, ordu içinde Alpaslan Türkeş gibi genç subayların planladığı, eyleme geçmemiş bir askeri darbe, hükümete yönelik Turancı bir komplo şeklinde yansıtılmıştır. Dava sürecinde aşırı sağcısından aşırı solcusuna kadar basının hep bir ağızdan ırkçılığı lanetleyen yayınları sayesinde de Milli Şef, Nazi döneminin bütün kir ve pasından pir-ü park arınmıştır.

Diğer taraftan Turancilık hareketinin desteklenmesi ve tasfiye edilmesi gibi Askeri Yargıtay' ın Birinci Sıkıyönetim Mahkemesi'nin kararını bozması ve başka bir mahkeme tarafından davaya yeniden bakılması, nihayetinde 1947'de sanıkların beraat etmeleri ve aklanmaları da yine dış politikadaki gelişmelerin iç politikadaki birer tezahürü olarak değerlendirilebilir. Nitekim 1944 yılında Sovyetler Birliği ile ilişkileri yumuşatmak adına Turancılara yönelik yapılan tasfiye operasyonu, 1945 yılının haziran ayında Sovyetler Birliği'nin Türkiye'nin doğu sınırında değişiklik yapılarak Kars ve Ardahan'ın kendisine bırakılmasını ve Boğazlar'da kendisine üsler verilmesini talep etmesi üzerine Türk-Sovyet ilişkilerinin tamamen kopma noktasına gelmesiyle anlamını ve işlevini yitirmiş bulunmaktaydı. Bu sürece paralel olarak Türk siyasetinde ve kamuoyunda yükselen antiSovyet ve anti-komünist söylem, milliyetçi söylemin yeniden yükselmesi için oldukça uygun bir ortam yaratmıştı. Koçak'a göre (1997) 1944 yilında suç olduğu düşünülen bir fikir ve eylem programı, 1947 yılının yeni koşullarında artık suç olmaktan çıkmıştı. Aksine, 1945-1946 yıllarından itibaren, durum yeniden değişmişti ve dış ilişkilere paralel olarak gelişen yeni iç politika konjonktüründe, milliyetçiliğin her derecesi ve her türlüsü, artık resmî söylemin ve tutumun belirgin bir göstergesiydi.

$\mathrm{Bu}$ süreçte ulusal basının konuya ve olaylara yaklaşımı da resmî ideolojiyle paralellik göstermiştir. Sabahattin Ali-Nihal Atsız davasının başlangıcından itibaren başta CHP'nin yayın organı Ulus gazetesi olmak üzere çalışma kapsamında incelenen bütün gazeteler ortak bir dil ve yaklaşımla sürece destek olmuşlardır. Ulus başyazarı ve CHP Milletvekili Falih Rıfkı Atay'ın yazılarıyla tavrı şekillenen ulusal basın, başlangıçta Sabahattin Ali-Nihal Atsız davasını üzerinde durulmaması gereken sıradan bir hakaret davası olarak lanse etmiştir. Fakat bütün gazetelerin davaya geniş yer vermesi ve hatta hükümetin Basın Yayın Genel Müdürlüğü aracılığıyla dava hakkında yayın yasağı getirmesi, konunun gerek hükümet gerekse basın tarafından basit bir hakaret davası olarak görülmediğinin; bunun da ötesinde ilerleyen günlerde Nihal Atsız'dan başlayıp bütün Turancı çevrelere yayılacak bir operasyonun ilk adımı olarak kabul edildiğinin açık bir göstergesidir. 
Benzer şekilde ortak bir dille 3 Mayıs olaylarını basit bir zabıta vakası olarak niteleyen gazeteler, gösterilere katılanlardan da 'kandırılmış bir avuç genç' diye bahsederken ırkçılığın ve Turancılığın Türkiye'de itibar görmeyen, marjinal ideolojiler olduğunu ispatlamaya çalışmışlardır. Yazarların ve gazetelerin hepsi ağız birliği yapmışçasına ırkçılığı lanetlerken sadece ırkçılığın değil solculuk, komünistlik gibi ideolojilerin de Türkiye' de yerinin olmadığını, devletin ve hükümetin bu ideolojilerin hiçbirine müsamaha göstermediğini sıkça dille getirmişlerdir. Hükümetin savaştaki denge politikasını destekler nitelikteki bu yayınlar ne Alman faşizminin ne de Sovyet komünizminin Türkiye' de yaşayamayacağını sıklıkla vurgulayarak aslında Türkiye' nin tarafsızlığını da ortaya koymaya çalışmışlardir.

18 Mayıs 1944'te yayınlanan tebliğ, Cumhurbaşkanı İsmet İnönü'nün 19 Mayıs nutku ve Falih Rıfkı Atay'ın yazılarını referans alarak yayın yapan ulusal basın gerek gözaltı gerekse dava sürecinde sanıklarla ilgili kesin ve suçlayıcı bir üslup benimsemiştir. Konuyla ilgili makale ve haberlerde sanıklar hakkında 'ırkçı' ve 'Turancı' tanımlamaları küçük düşürücü bir hakaret ya da olumsuzlama biçiminde kullanılmıştır. Böylece basının da desteğiyle Turancı çevreler sadece tasfiye edilmemiş aynı zamanda itibarsızlaştırılmıştır.

Bununla birlikte Ekim 1945'te Askeri Yargıtay'ın kararı bozması ve davanın yeniden başlatılmasıyla görünür hale gelen siyasi tavır değişikliği basının konuya yaklaşımında da kendini göstermiştir. Artık konuya daha temkinli yaklaşan gazeteler '1rkçı', '1rkçılık davası', 'suçlular' gibi kesin hüküm içeren ifadeler yerine 'ırkçılık sanıkları', 'maznunlar', 'Turancılık davası' gibi daha 1lımlı tanımlamalar kullanmışlardır.

\section{SONNOTLAR}

(1) Osmanlı'dan beri Turancılık kavramı, Pan-Türkizm kavramıyla eşanlamlı olarak kullanılmıştır. Landau, Turancılığı, Orta Asya bozkırlarında, sınırları tam olarak belirlenmemiş düşsel bir toprak parçasında yaşayan tüm halkların nihai birliği ve huzuru olarak tanımlamıştır. Yazara göre Macarlar, Finliler ve Estonyalıları da içine alan Turancılık, Pan-Türkizmi de kapsayan çok daha geniş bir kavramdır (Landau 1999: 10). Çünkü Turancılık, İran ve Afganistan'ın kuzeyinden Aral Gölü'ne ve doğuda Çin Türkistanı'nın sınırlarına kadar uzanan ve 'Turan' adı verilen coğrafi bölgede yaşayan bütün halklar arasındaki bir birliği ifade ederken, Pan-Türkizm, özel olarak bütün Türkî halklar arasında kültürel ya da siyasal bir anlama gelmektedir (Özdoğan 2002: 28-29).

(2) Bu dönemde Kopuz, Bozkurt, Hamle, Çınar, Çınaraltı, Tanrıdă̆, Türk Amacı, Gökbörü, Doğu, Türk Yurdu, Orhun gibi çok sayıda Turancı derginin yanı sıra bu minvalde 'Dalkavuklar Gecesi', 'Kızıl Tehlike', 'Kızıl Faaliyet', 'Gözümüzü Açalım', 'Gafletten Uyanalım', 'Hesap Veriyoruz' gibi isimlerle pek çok broşür de yayımlanmıştır. Berkes'e göre (2005: 274) bu tür yayınların propagandaları, Tu- 
rancılığın eylem aşamasına gelmesi halinde maneviyatı hazır düzeyde tutmak gibi bir işe yarıyordu.

(3) 8 Temmuz 1942 tarihinde Refik Saydam'ın ani ölümü üzerine Başbakanlık görevine getirilen Şükrü Saraçoğlu 5 Ağustos 1942 tarihli Meclis toplantısında kabinesinin programını okuyarak Meclis'ten güvenoyu istemiştir. Saraçoğlu konuşmasında "Arkadaşlar, Biz Türküz, Türkçüyüz ve daima Türkçü kalacağı. Bizim için Türkçülük bir kan meselesi oldŭ̆u kadar ve lâakal o kadar bir vicdan ve kültür meselesidir. Biz azalan ve azaltan Türkçü değil, çoğalan ve çoğaltan Türkçüyüz ve her vakit bu istikamette çalışacağız." sözleriyle kurduğu hükümetin Türkçülük konusundaki yaklaşımını ortaya koymuştur (TBMM Zabıt Ceridesi 1942: 24-25).

(4) Sabahattin Ali ile Nihal Atsız arasındaki çatışma aslında iki boyutluydu. Birincisi yukarıda anlatıldığı gibi ideolojik bir kutuplaşmadan kaynaklanıyordu. Ama bu çatışmanın Sabahattin Ali'nin 1939'da yayınladığı 'İçimizdeki Şeytan' adlı romanı nedeniyle ikisi arasında çıkan kavga ile ilgili başka bir boyutu da vardı. Romandaki kimi karakterlerin Sabahattin Ali tarafından Türkiye'deki kimi milliyetçilere leke sürmek amacıyla yaratıldığını iddia eden Atsız, Sabahattin Ali'ye misillemede bulunmak için 'İçimizdeki Şeytanlar' adlı kitabını yayınlamışt1 (Özdoğan 2002: 102-103).

(5) 'Ankara nümayişi' olarak bilinen bu gösterilerin yaşandığı 3 Mayıs günü, sonraki yıllarda Türkçü ve milliyetçi çevrelerce milli direnişi simgeleyen tarihi bir gün olarak kabul edilmiş ve 'Türkçülük Günü' olarak kutlanmaya başlamıştır.

(6) Pek çok kaynak, Atay’ın bir avuç diye bahsettiği kalabalığın binlerce kişiden oluştuğunu yazmaktadır.

(7) Henüz savaş devam ettiği ve Türkiye Almanya ile ilişkilerini devam ettirdiği için Atay 3 Mayıs göstericilerini Almanya'daki Nazilere benzetmek yerine Romanya'daki Gardistlere benzetmeyi tercih etmiştir.

(8) Hasan Ali Yücel Maarif teşkilatına gönderdiği bir tamimle Milli Şef İsmet İnönü'nün 19 Mayıs 1944 nutkunun 1944-45 ders yılının ilk gününde ilkokulların son iki sınıflarında; ortaokulların, liselerin, öğretmen okullarının, teknik öğretim kurumlarının ve köy enstitülerinin bütün sınıflarında; yüksek okullarla yüksek teknik kurumlarının, üniversitenin, fakültelerin, köy enstitüsü yüksek kısmının açılış derslerinde okunması emrini vermiştir. Ayrıca tamime göre ilkokullar, ortaokullar ve bu derecedeki diğer okulların yurt bilgisi derslerinde; lise ve dengi okulların sosyoloji, tarih ve inkılap tarihi derslerinde öğretim, nutukta yazılı esaslara göre yapılacak, metnin çeşitli parçaları üzerinde durulacaktı. Yüksek öğretim kurumlarında ise ahlak, sosyoloji gibi toplumla ilgili derslerle Türk İnkılap Tarihi ve Türkiye Cumhuriyeti Rejimi derslerini veren profesörler bu nutkun ruhuna uygun, halkın rahatlıkla okuyabileceği broşürler yazıp, basılmak üzere resmi yollardan Maarif Vekaleti'ne göndereceklerdi (Darendelioğlu 1968: 73). 
(9) Tutuklanan bazı isimlerin anılarında aktardıklarına göre bu süreçte tutuklulara çeşitli işkenceler uygulanmış, tutuklular kendilerine isnat edilen suçları kabul edecek şekilde ifade vermeye zorlanmıştır. Mezarlık hücresi adı verilen, o dönem İstanbul Emniyet Müdürlüğü binası olarak kullanılan Sanasaryan Hanı'nın yeraltı katında yer alan, lağım suyu, rutubet, böcek gibi sağlıksız koşullara sahip hücrelerde tutulmak; aç ve susuz bırakılmak, dayak ve falaka, ölüm tehdidi, tabutluk adı verilen hücrelerde tutulmak gibi farklı işkence yöntemleri kullanılmıştır (Darendelioğlu 1968: 74-98, Türkeş 1972: 57-67, Türkkan 2011: 143-146). Bunlardan en acımasız ve etkilisi 'tabutluk' adı verilen hücrelerdir. Bu hücreye tabutluk denmesinin nedeni yetişkin bir insanın ancak sığabileceği boyutlarda, dikine oturtulmuş bir tabut şeklinde olmasıdır. Türkkan'ın anlattığına göre (2011: 143-146) tabutluk, içine konulan kişinin bileklerinden kelepçeyle tavana asıldığı ve ayaklarının yere değmediği; başının birkaç karış üstünde, her biri o zamanki sokak ampulleri kadar büyük, içinde 2000 mumluk filamanları olan iki-üç ampulün yandığı bir işkence odasıydı. Dönemin polis müdürü Haluk Pepe'nin, Nazi Almanya'sına yaptığı bir seyahat esnasında öğrenip uygulamaya koyduğu bir işkence tekniğiydi.

(10) Güzel'in iddiasına göre (1997: 34) Reha Oğuz Türkkan, Türk soyundan gelmeyenlerin elindeki hükümeti silah gücüyle devirip yerine ırkçı ve Turancı bir hükümet kurmak amacıyla 'Gurem' adında gizli bir örgüt kurmuştur. Türkkan örgütün amacını gizlemek üzere 'Kitapseverler Kurumu' adında bir dernek kurmuş, çalışmalarını bu dernek aracılığıyla sürdürmüştür. Diğer taraftan Reha Oğuz Türkkan (2011: 101) Sabahattin Ali-Nihal Atsız davasını protesto etmek üzere düzenlenen gösterileri organize etmek için Ankara'ya gittiğini ve 3 Mayıs 1944 günü onbine yakın genci sokaklara döküp Atsız'1 destekleyen yürüyüşler yaptırdığını kabul etmekte; fakat iddia edildiği gibi hükümeti devirmek amacıyla gizli örgüt kurmak suçlamasını şu sözlerle reddetmektedir: "Bizim darbe yapacak gücümüz zaten yoktu: çoğu öğrenci ve öğretmen bir avuç idealist gençlerle iki üç de profesördük topu topu. 3 Mayıs yürüyüşümüzde onbin kişi toplanmıştık ama bunların çoğu meraktan katılan kalabalıktı. Aramızda darbeye inanılırlık verecek askerde yoktu: Türkeş genç bir teğmendi, üniformalı 4 kadar tutuklumuz da yedek subaylı̆̆ın yapan üniversite mezunlarıydı!" (Türkkan 2011: 125).

(11) Tan gazetesi Bakanlar Kurulu kararıyla 12 Ağustos 1944-28 Mart 1945 tarihleri arasında kapalı olduğu için burada Tan yer almamaktadır. Ayrıca gazete, 4 Aralık 1945 tarihinde yaşanan saldırı ve yağmalama sonucunda yayın hayatına son verdiği için bu tarihten sonra da çalışma kapsamında incelemeye dahil edilememiştir.

\section{KAYNAKÇA}

Atsız N (1 Mart 1944) Başbakan Saraçoğlu Şükrü’ye Açık Mektup, Orhun, Sayı: $15,1-4$. 
Atsız N (1 Nisan 1944) Başbakan Saraçoğlu Şükrü'ye İkinci Açık Mektup, Orhun, $16,1-6$.

Ayın Tarihi, Sayı: 126, Mayıs 1944.

Berkes N (2005) Unutulan Yıllar, Ruşen Sezer (yay. haz.), İletişim Yayınları, İstanbul.

Darendelioğlu İ (1968) Türkiye'de Milliyetçilik Hareketleri, Toker Yayınları, İstanbul.

Glasneck J (1976) Türkiye' de Faşist Alman Propagandası, Arif Gelen (çev.), Onur Yayınları, Ankara.

Goloğlu M (1974) Milli Şef Dönemi (1938-1945), Kalite Matbaası, Ankara.

Gözaydın N (2002) Türk Basınında Germanofiller, Tarih ve Düşünce Dergisi, 2002/4, 18-29.

Güvenir O M (1991) 2. Dünya Savaşı'nda Türk Basını, Gazeteciler Cemiyeti Yayınları, İstanbul.

Güzel M Ş (1997) Türk Usulü Demokrasi, Doruk Yayımcılık, Ankara.

Kabacalı A (1987) Milli Şef Döneminin Örtülü Sansürü, Tarih ve Toplum Dergisi, $38,19-21$.

Koçak C (1997) Öner-Yücel Davası, Tarih ve Toplum Dergisi, 166, 23-30.

Landau J M (1999) Pantürkizm, Mesut Akın (çev.), Sarmal Yayınevi, İstanbul.

Müftüoğlu M (1974) Çankaya'da Kâbus (3 Mayıs 1944), Yağmur Yayınları, İstanbul.

Özdoğan G G (2002) “Turan”dan “Bozkurt”a Tek Parti Döneminde Türkçülük (1931-1946), İletişim Yayınları, İstanbul.

Sülker K (1968) Sabahattin Ali Dosyası, Ant Yayınları, İstanbul.

TBMM Zabit Ceridesi (1942) Devre: 6, Cilt: 27, İçtima:2, 77. İnikat (05.08.1942), TBMM Matbaası, Ankara.

Türkeş A (1972) 944 Milliyetçilik Olayı, Kutluğ Yayınları, İstanbul.

Türkkan R O (2011) Arayan Adam (II. Cilt), Pozitif Yayınlar, İstanbul.

\section{Gazeteler}

Akşam

Cumhuriyet

Tan

Tanin

Ulus 
Selçuk İletişim, 2018, 11 (1): 212-236

Vakit 